\title{
Article \\ Self-Cleaning Performance of Super-Hydrophilic Coatings for Dust Deposition Reduction on Solar Photovoltaic Cells
}

\author{
Wenjun Zhao ${ }^{1}$ and Hao $\mathrm{Lu}^{1,2, *}$ \\ 1 Department of Electrical Engineering, Xinjiang University, Urumqi 830047, China; zhaowjhku@gmail.com \\ 2 School of Future Technology, Xinjiang University, Urumqi 830047, China \\ * Correspondence: luhao@xju.edu.cn
}

Citation: Zhao, W.; Lu, H.

Self-Cleaning Performance of

Super-Hydrophilic Coatings for Dust

Deposition Reduction on Solar

Photovoltaic Cells. Coatings 2021, 11,

1059. https://doi.org/10.3390/

coatings11091059

Academic Editor:

Ioannis Karapanagiotis

Received: 31 July 2021

Accepted: 30 August 2021

Published: 2 September 2021

Publisher's Note: MDPI stays neutral with regard to jurisdictional claims in published maps and institutional affiliations.

Copyright: (C) 2021 by the authors Licensee MDPI, Basel, Switzerland. This article is an open access article distributed under the terms and conditions of the Creative Commons Attribution (CC BY) license (https:/ / creativecommons.org/licenses/by/ $4.0 /)$.

\begin{abstract}
Dust deposition on solar photovoltaic (PV) cell surface will significantly decrease the PV power efficiency, as the transmittance of the solar cells would be greatly decreased by the deposited dust particles. This paper aims to study the anti-dust performance of super-hydrophilic coatings for the solar PV cells with water spraying condition. The solar cell covering glass was treated to be super-hydrophilic and compared with the bare glass sample. It was found that many dust particles adhere and aggregate on the uncoated glass while the particles deposited on the super-hydrophilic glass surface are densely distributed. When the water spraying process was conducted, the dust deposition mass for the bare and the coated glass samples are both reduced obviously with the increase time of water spraying. In addtion, dust deposition mass is significantly reduced with the increase of deposition and spraying tilt angles. The self-cleaning efficiency of super-hydrophilic coating on dust deposition is $92 \%$ higher than the bare glass cases. The spectral transmittance of glass samples for all the coated cases are significantly higher than that for all the bare cases. The maximum transmittance improvement can reach $26.5 \%$ when the deposition tilt angle is $30^{\circ}$ and the spraying tilt angle is $60^{\circ}$.
\end{abstract}

Keywords: dust deposition; super-hydrophilic coating; solar photovoltaic; spectral transmittance; self-cleaning

\section{Introduction}

Solar photovoltaic (PV) technology is a kind of promising and clean energy application and widely applied all around the world. However, the output efficiency of the solar PV panels can be greatly reduced due to dust deposition [1-3]. This is due to the fact that the transmittance of solar cell covering glass is reduced by deposited dust particles. Water washing is the common way to reduce the dust deposition problem. Nevertheless, the direct water cleaning method has a high cost and is not efficient. Thus, new cleaning methods are needed to be developed to reduce dust deposition on solar cells.

The effects of dust deposition on the solar PV system have been well studied and it was found that the power loss of photovoltaic panels can reach up to $70 \%$ due to the deposition of dust [4-6]. Goossens et al. [7] studied the effect of wind velocity on the dust accumulation rates on photovoltaic cells. They found that the PV efficiency decreases with the increase of gas flow due to the larger dust deposition rate. Lu et al. [8-10] studied dust deposition behaviours on solar cells by CFD simulation. The results showed that medium dust has the highest deposition rate on solar cess. However, the effective solutions for the dust deposition problem were not proposed in the above studies.

Self-cleaning materials including super-hydrophobic and super-hydrophilic coatings have been applied for solar PV panels due to their surface wettability and surface microstructure [11-14]. Piliougine et al. [15] prepared a super-hydrophobic coating to reduce dust deposition on photovoltaic systems. They found that the self-cleaning coating can significantly improve the performance of photovoltaic power generation reduction caused 
by dust deposition. Quan et al. [16] proposed a kind of hydrophobic coating for solar photovoltaic cover glass. The low adhesion force of hydrophobic coatings can result in the decrease of dust deposition. Recently, the authors $[17,18]$ investigated the effect of superhydrophobic surface on dust deposition for different surface structures and dust properties. It was found that the super-hydrophobic surface can significantly decrease the dust deposition rate even without water due to the low surface energy and surface micro-structure.

For super-hydrophilic coating, Prabhu et al. [19] prepared super-hydrophilic and selfcleaning coatings for solar PV cells. The coating can decontaminate the adsorbed pollutants under experimental conditions. Moreover, Lei et al. [20] proposed highly transparent and super-hydrophilic coatings on glass by modified $\alpha$-zirconium phosphate nanoplatelets. The results showed that the contact angle of the coating can reach nearly $0^{\circ}$ and can be used on the solar cell. Centeno et al. [21] developed photonic front-coatings to improve the output efficiency of thin-film solar cells due to the self-cleaning property. The coating was developed by structuring parylene-C transparent encapsulants using a low-cost and highly-scalable colloidal-lithography methodology. The short-circuit current density of nanocrystalline silicon solar cells is improved up to $23.6 \%$ when using the self-cleaning coating, compared to planar reference cells. This is due to the fact that the optimized coatings present high water contact angles and extremely low adhesion. Moreover, the nano/micro-structures of the coatings show strong anti-reflection and light scattering effects. Khan et al. [22] developed an automatic self-cleaning mechanism (ASCM), which is efficient and low-cost. The experimental results showed that the PV output efficiency can be improved for 35\% by the ASCM. Lebbi et al. [23] proposed a new hybrid system PV/T Bi-fluid that combines both active cooling and self-cleaning technique simultaneously to improve the solar panel electrical performance. The average temperature of the new hybrid system can be decreased by $15{ }^{\circ} \mathrm{C}$, compared to the reference case. Moreover, the electrical efficiency is also improved for about $5.7 \%$, compared to the reference case. Allouhi et al. [24] developed a new multi-objective optimization approach to optimize economically and environmentally the implementation of solar photovoltaic systems for self-consumption under the scenario of zero export injection. This optimized design leads to the best compromise between economic and environmental aspects. The corresponding self-sufficiency and self-consumption ratios are estimated at 41.41 and $79.14 \%$, respectively. Roslizar et al. [25] induced super-hydrophobicity by hot-embossing random micro textures on a highly transmissive and photostable fluorinated ethylene propylene (FEP) film. The self-cleaning properties of the textured FEP films result in a recovery ratio of $93.6 \%$, which is greatly higher than that of the reference glass encapsulated PV mini-module (61.1\%). Liu et al. [26] developed a new superhydrophobic $\mathrm{PVDF} / \mathrm{SiO}_{2}$ composite film based on a well-constructed PVDF surface. The results showed that the self-cleaning property of the coating can be regenerated and maintained easily. Mouchaal et al. [27] fabricated transparent thin films of $\mathrm{Ag}+1-\mathrm{In}+3$ co-doped $\mathrm{SnO}_{2}$ using robotic spray pyrolysis. The optical transmittance reaches from 90.3 to $82.7 \%$, when the Ag+1 doping ranges from 0 to 12 at $\%$. The best stable generated photocurrent can be achieved for samples with 12 at $\% \mathrm{Ag}+1$. Sangchay [28] prepared $\mathrm{TiO}_{2}$ doped with $\mathrm{SnO}_{2}$ thin films using the sol-gel approach. They found that photocatalytic and self-cleaning performances of $\mathrm{TiO}_{2}$ doped with $1 \mathrm{~mol} \%$ of $\mathrm{SnO}_{2}$ thin films are maximum under fluorescent irradiation. Yiu et al. [29] developed a convenient method of depositing a stainless steel-like hydrophilic coating. The textured film deposited at 12 mTorr shows high hydrophilicity and low contact angle hysteresis (CAH).

Self-cleaning surfaces for solar PV panels have been investigated by the researchers. However, most studies focused on super-hydrophobic surface performance on dust deposition reduction on solar PV panels. The self-cleaning performance and mechanism of the super-hydrophilic coating under the water spraying condition have not been investigated. Rainfall or artificial water cleaning is the common way to enhance the cleaning performance of super-hydrophilic surface. Therefore, this paper aims to study the selfcleaning performance of super-hydrophilic coatings on dust deposition reduction on solar 
PV cells under the water spraying condition. The solar cell covering glass was treated to be super-hydrophilic and compared with the bare glass sample. The micro-patterns of deposited dust, the dust deposition density, and the transmittance of covering glass for bare and coated glass samples were investigated, which may be helpful for the self-cleaning technology on solar PV soiling.

\section{Experiments}

\subsection{Experimental Methodology}

The test schematic of dust deposition on solar cell covering glass can be seen in Figure 1. The solar cell covering glass samples were placed in the chamber. The size of test chamber is $0.8 \times 0.5 \times 0.5 \mathrm{~m}^{3}$. The dust was generated from a particle generator and then released to the chamber. A fan was used to simulate the natural wind. The dust particles will naturally fall on the solar cell surface. The total deposition time was $60 \mathrm{~min}$ and the total spraying time was 9 min during the spraying experiment. Dust deposition density was measured per $3 \mathrm{~min}$ while the volume water of spraying was $1.5 \mathrm{~mL} / \mathrm{s}$. The tilt angle is 30 or $60^{\circ}$ in the study, respectively. Coated and bare glass samples were used for comparison in the experiment. The detailed experimental cases can be seen in Table 1.

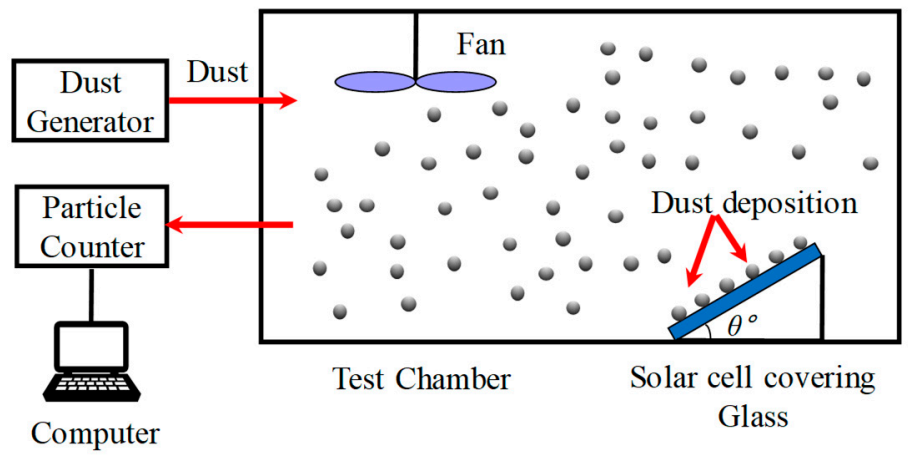

(a) Schematic diagram.

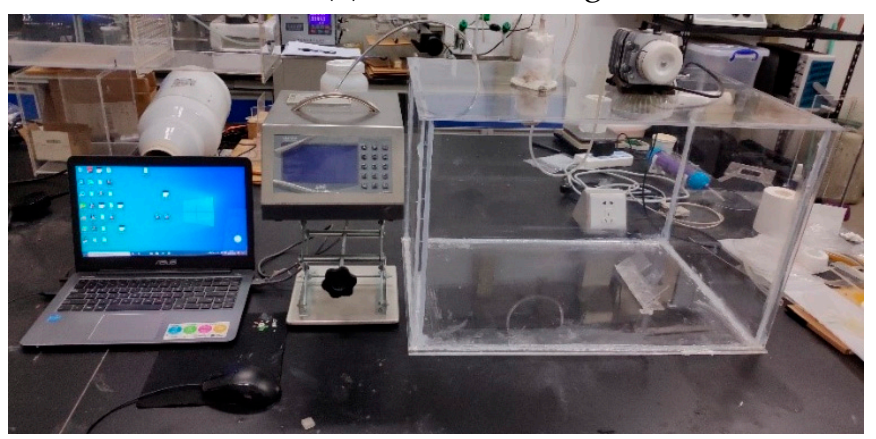

(b) Real diagram.

Figure 1. Experimental schematic of dust deposition on solar cell covering glass.

A contact angle meter (OCA20, Dataphysics, Filderstadt, Germany) was adopted to measure the contact angles of glass samples. A precious balance (FX-2001IWP, Guangzhou, China) was used to measure the dust deposition density of glass samples. A scanning electron microscope (SEM, S-8820, HITACHI, Tokyo, Japan) was used to scan the surface morphology of glass samples to obtain the micro patterns. Moreover, a UV spectrometer (U-3010, Tokyo, Japan) was adopted to examine the transmittance of the glass samples before and after dust deposition. 
Table 1. Experimental cases.

\begin{tabular}{cccc}
\hline Number & Surface & $\begin{array}{c}\text { Tilted Angle for } \\
\text { Dust Deposition }\end{array}$ & $\begin{array}{c}\text { Tilted Angle for } \\
\text { Water Spraying }\end{array}$ \\
\hline$A$ & bare & $\theta=30^{\circ}$ & $\theta=30^{\circ}$ \\
$A^{*}$ & coated & $\theta=30^{\circ}$ & $\theta=30^{\circ}$ \\
$B$ & bare & $\theta=30^{\circ}$ & $\theta=60^{\circ}$ \\
$B^{*}$ & coated & $\theta=30^{\circ}$ & $\theta=60^{\circ}$ \\
$C$ & bare & $\theta=60^{\circ}$ & $\theta=30^{\circ}$ \\
$C^{*}$ & coated & $\theta=60^{\circ}$ & $\theta=30^{\circ}$ \\
$D$ & bare & $\theta=60^{\circ}$ & $\theta=60^{\circ}$ \\
$D^{*}$ & coated & $\theta=60^{\circ}$ & $\theta=60^{\circ}$ \\
\hline
\end{tabular}

\subsection{Super-Hydrophilic Coating}

The $\mathrm{TiO}_{2}$ and $\mathrm{SiO}_{2}$ sol were prepared with tetrabutyl titanate and ethyl silicate, respectively. The substance purities of the tetrabutyl titanate and ethyl silicate are greater than $98 \%$. Tetrabutyl titanate was mixed with ethanol and stirred for $0.5 \mathrm{~h}$. Then, the acetic acid, distilled water, and ethanol were added to the mixture of Tetrabutyl titanate and ethanol. After that, the mixture solution was stirred at room temperature and the $\mathrm{TiO}_{2}$ sol can be obtained. Meanwhile, the $\mathrm{SiO}_{2}$ sol was fabricated by the mixture of ethyl silicate, ethanol, and polyethylene glycol. The prepared $\mathrm{TiO}_{2}$ and $\mathrm{SiO}_{2}$ sol were mixed and continuously stirred for $4 \mathrm{~h}$. Finally, the sol was evenly coated on the bare glass sample and dried at the temperature of $40^{\circ} \mathrm{C}$ for $3 \mathrm{~h}$. Figure 2 shows the contact angle of the glass sample with and without super-hydrophilic coatings. The contact angle of the bare glass was about $42^{\circ}$ while that of the glass sample with the super-hydrophilic coating was about $5^{\circ}$. The droplet can be spread more widely on the coated glass sample. Thus, it is easier to form a water film flow to take away the deposited dust on the surface by super-hydrophilic coating.

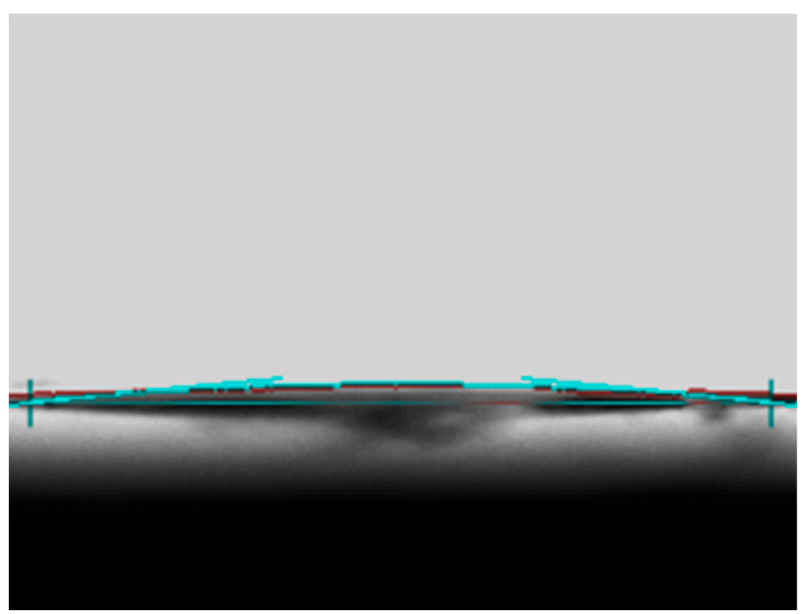

(a) Glass with super-hydrophilic coating.

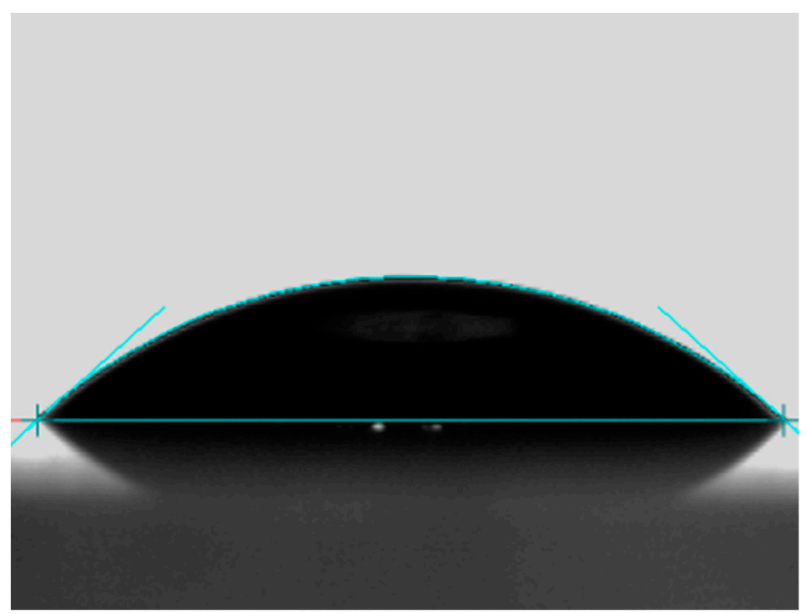

(b) Glass without super-hydrophilic coating.

Figure 2. Contact angles of glass surfaces with and without super-hydrophilic coating.

\subsection{Test Dust}

The test dust (ISO 12103-1 A2, Powder Technology Inc., Arden Hills, MN, USA) was used in the experiment. The cumulative volume fraction of dust particle size is shown in Figure 3. The cumulative volume fraction of particles less than $22 \mu \mathrm{m}$ is $75 \%$. Table 2 provides a list of dust particles chemical components. 


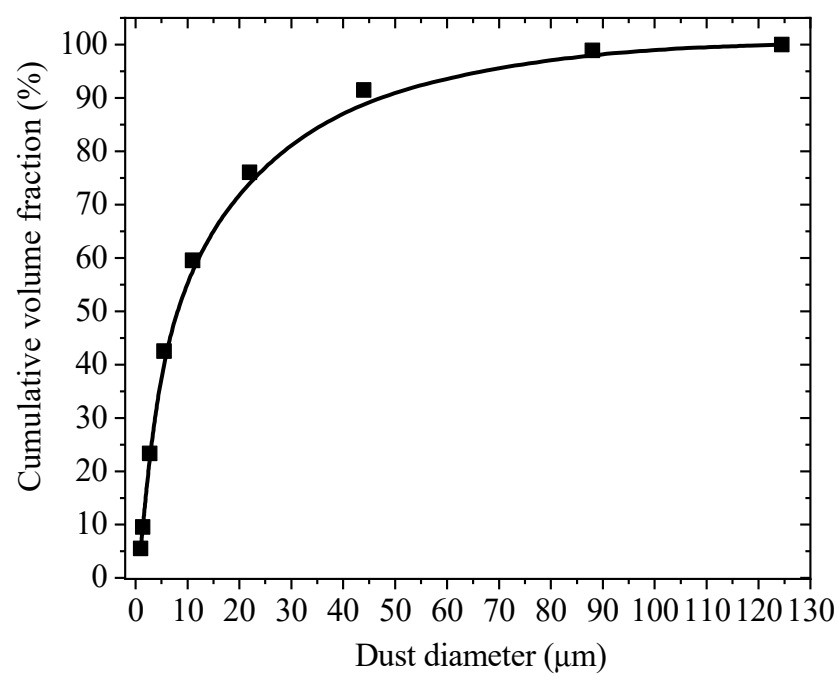

Figure 3. Cumulative volume fraction of dust particle size.

Table 2. Chemical components of test dust.

\begin{tabular}{cccc}
\hline Chemical & \% of Weight & Chemical & \% of Weight \\
\hline $\mathrm{SiO}_{2}$ & $69-77$ & $\mathrm{CaO}$ & $2.5-5.5$ \\
$\mathrm{Al}_{2} \mathrm{O}_{3}$ & $8-14$ & $\mathrm{MgO}$ & $1.0-2.0$ \\
$\mathrm{Fe}_{2} \mathrm{O}_{3}$ & $4-7$ & $\mathrm{TiO}_{2}$ & $0-1.0$ \\
$\mathrm{Na}_{2} \mathrm{O}$ & $1-4$ & $\mathrm{~K}_{2} \mathrm{O}$ & $2.0-5.0$ \\
\hline
\end{tabular}

\section{Results and Discussion}

\subsection{Dust Deposition Patterns}

The scanning electron microscope (SEM) was used to measure the micro-patterns of dust particles on the glass surface. The results were shown in Figure 4. A large amount of dust particles adhere and aggregate on the surface of the bare glass. In addition, the diameter of dust particles deposited on the bare glass samples is larger than $200 \mathrm{~nm}$. However, the particles deposited on the glass sample with super-hydrophilic coatings are densely distributed on the surface. It seems that no very large particles are adhered on the super-hydrophilic surface. It indicates that the dust particles are easier to deposit on the super-hydrophilic coating due to the high surface energy, especially for small dust particles.

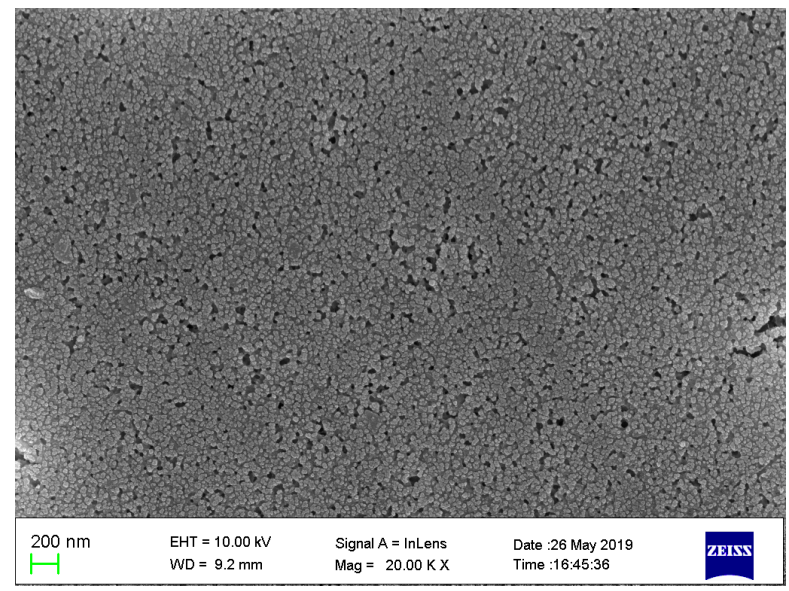

(a) Coated glass.

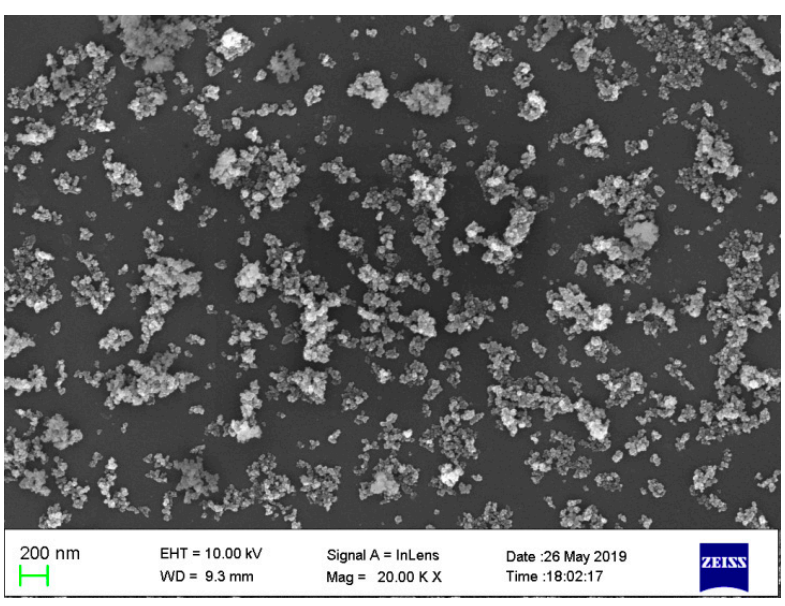

(b) Uncoated glass.

Figure 4. Deposited dust patterns with and without super-hydrophilic coating. 


\subsection{Effects of Super-Hydrophilic Coating on Dust Deposition}

When water droplets contact the super-hydrophilic surface, the water film will be formed on the surface due to the super-hydrophilic property and the water film flow will take the deposited dust particles away from the surface due to gravitation. Thus, the superhydrophilic surface has a self-cleaning performance on the dust deposition. In the present study, the dust particles were naturally deposited on the glass samples. Then, the water spraying was used to wet the glass sample surfaces. The dust deposition time was $60 \mathrm{~min}$ and the total spraying time was $9 \mathrm{~min}$. The tilt angle is $30^{\circ}$ or $60^{\circ}$ in the deposition process and water spray process, respectively. The detailed experimental cases can be found in Table 1 . During the spraying experiment, the dust deposition density was measured every $3 \mathrm{~min}$ and the flow rate of spraying was $1.5 \mathrm{~mL} / \mathrm{s}$.

The dust deposition mass on the glass samples was obtained, as shown in Figure 5. As can be seen from Figure $5 \mathrm{a}, \mathrm{b}$, the dust deposition mass on the glass sample with superhydrophilic coating is obviously less than that on the bare glass sample before the water spraying, when the tilt angle is $30^{\circ}$. It indicates that the super-hydrophilic surface could decrease dust deposition to a certain degree without water. It may be caused by the micronano structures on the super-hydrophilic surface. However, when the tilt angle is $60^{\circ}$, the dust deposition mass on the glass sample with super-hydrophilic coatings is more than that on the bare glass sample before water spraying, as shown in Figure $5 c, d$. This is due to the fact that the dust particles on the bare glass sample are easier to roll down from the surface, compared with the coated glass sample. When the water spraying was conducted, the dust deposition mass for bare and coated glass samples are both reduced obviously with the increased time of water spraying. The dust deposition mass on the coated glass sample is obviously lower compared with the bare glass sample. This indicates that the super-hydrophilic coating has a significantly self-cleaning ability.

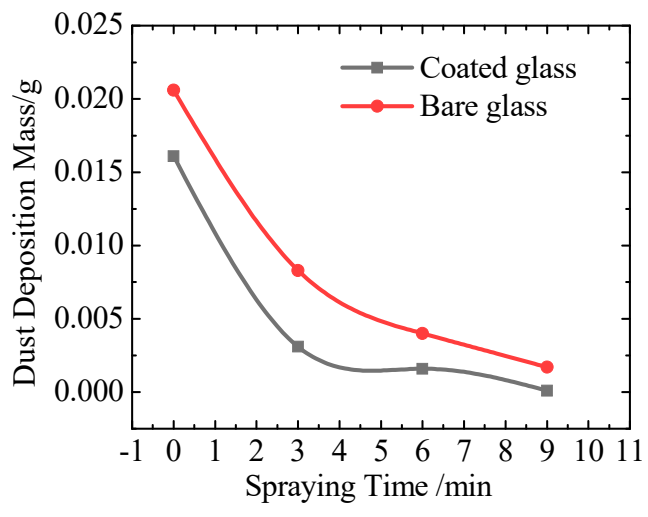

(a) Case $A$ and $A^{*}$.

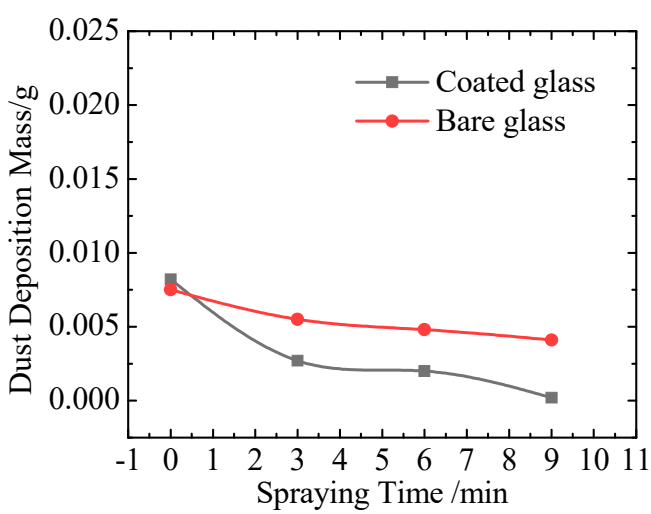

(c) Case $C$ and $C^{*}$.

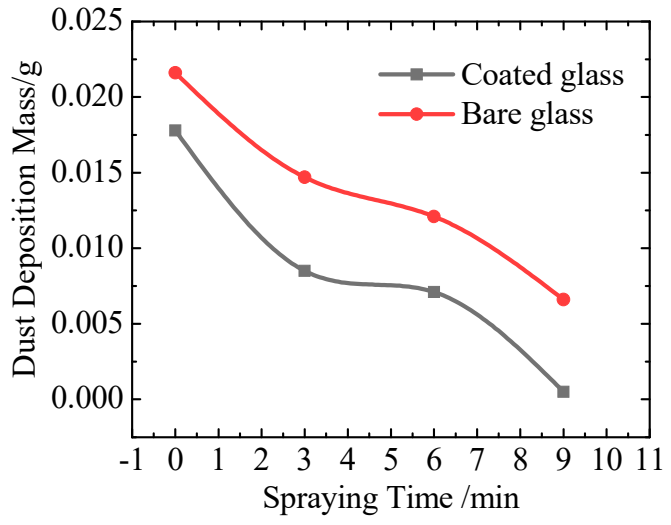

(b) Case $B$ and $B^{*}$.

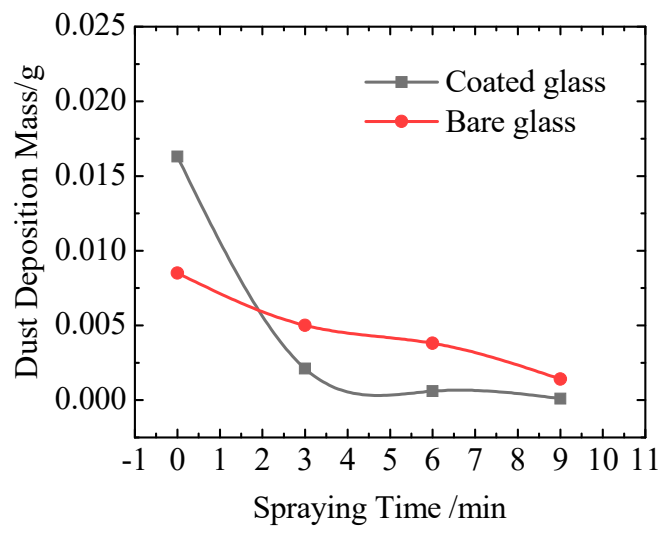

(d) Case $D$ and $D^{*}$.

Figure 5. Effect of super-hydrophilic coating on the dust deposition mass. 
Figure 6a shows the influence of tilt angle on the dust deposition mass on solar cells without using the super-hydrophilic coating. When the tilt angle of dust deposition is $30^{\circ}$, the dust deposition mass for the bare glass cases is 6.6 and $1.7 \mathrm{mg}$ for the water spraying of $30^{\circ}$ and $60^{\circ}$, respectively. When the tilt angle of dust deposition increases to $60^{\circ}$, the dust deposition mass for the bare glass cases is 4.1 and $1.4 \mathrm{mg}$ for the water spraying of $30^{\circ}$ and $60^{\circ}$, respectively. Therefore, the tilt angles of the dust deposition and water spraying can both reduce the dust deposition due to the gravitation. Figure $6 \mathrm{~b}$ shows the dust deposition mass on the glass samples with super-hydrophilic coating. When the tilt angle of dust deposition is $30^{\circ}$, the dust deposition mass for the coated glass cases is 0.5 and $0.1 \mathrm{mg}$ for the water spraying of $30^{\circ}$ and $60^{\circ}$, respectively. When the tilt angle of dust deposition increases to $60^{\circ}$, the dust deposition mass for the coated glass samples is 0.2 and $0.1 \mathrm{mg}$ for the water spraying of $30^{\circ}$ and $60^{\circ}$, respectively. The dust deposition mass is obviously decreased by the super-hydrophilic coating, compared with the bare glass cases. In addition, the dust deposition mass is obviously decreased with the increasing of deposition and spraying tilt angles.

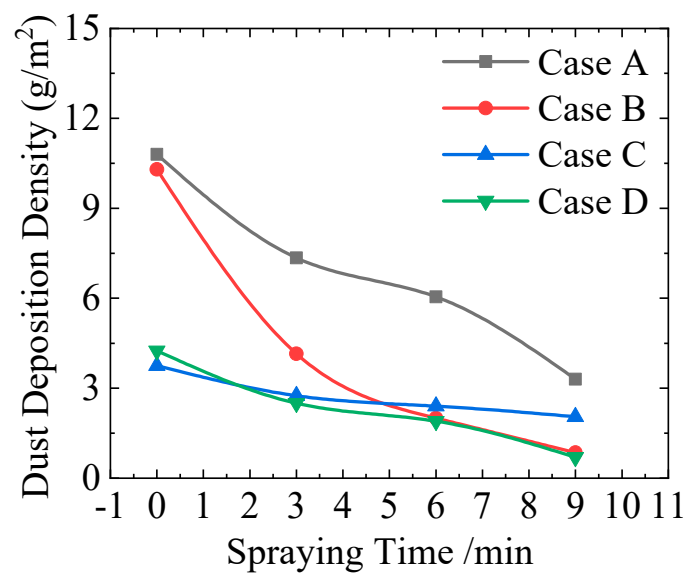

(a) Bare glass.

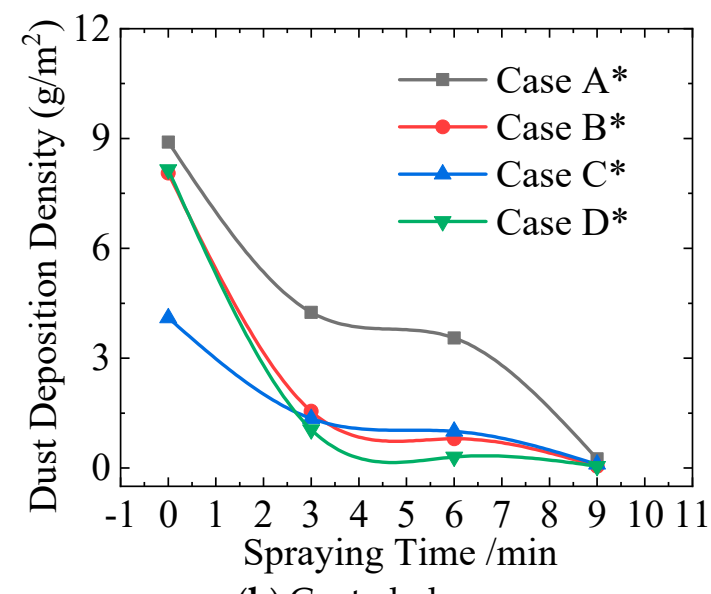

(b) Coated glass.

Figure 6. Effect of tilt angle on the dust deposition density.

When the tilt angle is $30^{\circ}$, the dust deposition density on the coated glass is just about $5.9 \%$ and $7.6 \%$ of that on the bare glass after the water spraying for the spraying angle of $30^{\circ}$ and $60^{\circ}$, respectively. When the tilt angle is $60^{\circ}$, the dust deposition density on the coated glass is just about $4.9 \%$ and $7.1 \%$ of that on the bare glass after the water spraying for the spraying angle of $30^{\circ}$ and $60^{\circ}$, respectively. Therefore, the self-cleaning efficiency of the super-hydrophilic coating is $92 \%$ higher than the bare glass cases. Moreover, the dust deposition reduction between the bare and coated glass samples is a little lower when the water spraying angle is higher. This is due to the fact that more deposited particles will be taken away by the water droplet from the surface of the bare glass sample.

\subsection{Spectral Transmittance}

The main mechanism of dust deposition to reduce the efficiency of solar PV cells is the spectral transmittance degradation of the solar cell covering glass. Therefore, the effect of the deposited dust particles on the glass transmittance was examined in this study. As seen from Figure 7, the average spectral transmittance of the super-hydrophilic coated glass samples $\left(A^{*}, B^{*}, C^{*}, D^{*}\right)$ is higher than that of the bare glass cases $(A, B, C, D)$. For the coated glass cases, the transmittance of $A^{*}, B^{*}, C^{*}$, and $D^{*}$ is $85.80 \%, 90.62 \%, 87.99 \%$, and $94.72 \%$, respectively. Thus, the glass samples with a large tilt angle generally have a higher spectral transmittance. Moreover, the spectral transmittance of the sample $B^{*}$ is $2.62 \%$ higher than that of sample $C^{*}$. 


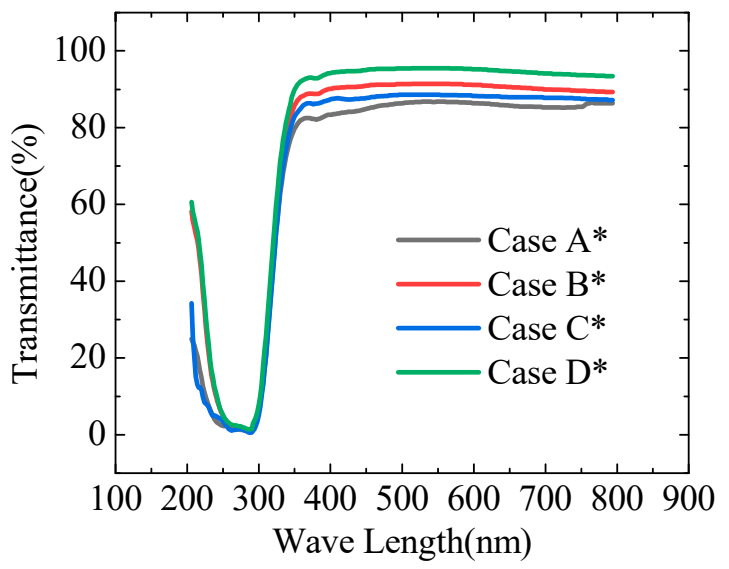

(a) Coated glass.

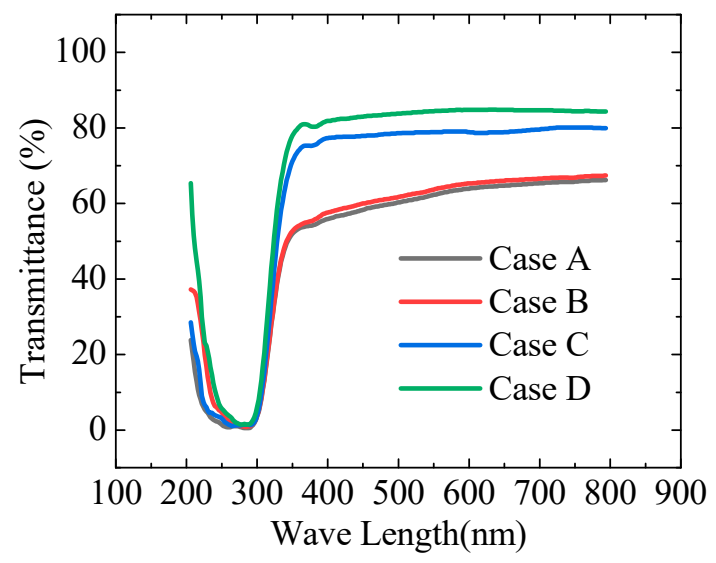

(b) Bare glass.

Figure 7. Effects of tilt angle on the spectral transmittance of glass samples.

For the bare glass sample cases, the spectral transmittance of the four groups $A, B, C$, and $D$ is $62.75 \%, 64.12 \%, 78.95 \%$, and $84.16 \%$, respectively. The transmittance of the glass sample reaches the highest when the tilt angles of the dust deposition and water spraying are both $60^{\circ}$. However, different from the coated glass cases, the spectral transmittance of Case B is higher than that of Case C. It means that the influence of spraying tilt angle on bare glass is smaller than the deposition tilt angle, which is due to the fact that the mechanism of dust deposition reduction for the bare glass case and the coated glass case is quite different. The former is mainly caused by the gravitation and the latter is due to the water film flow. More importantly, the spectral transmittance for all coated cases is significantly higher than that for all the bare cases, as shown in Figure 8. The maximum transmittance improvement can reach $26.5 \%$ when the deposition tilt angle is $30^{\circ}$ and the spraying tilt angle is $60^{\circ}$. For the influence of dust deposition density on the PV output efficiency, the relationship of efficiency of the generation and deposition density was obtained by Jiang et al. [30]. It can be found that the PV efficiency reduction is generally linear with the dust deposition density.

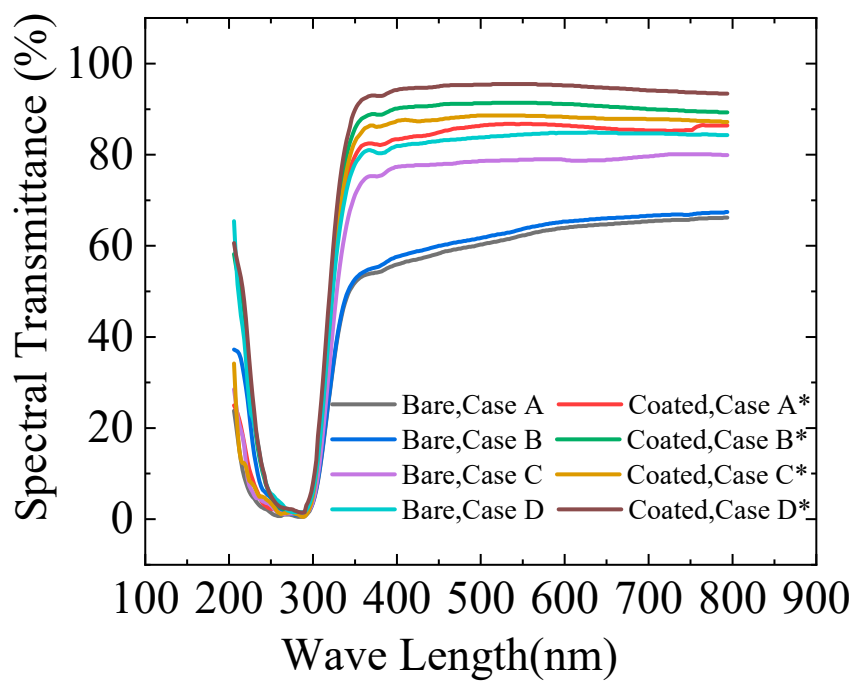

Figure 8. Comparison of spectral transmittance for the bare and coated glass cases.

\section{Conclusions}

The self-cleaning performance of the super-hydrophilic coating on dust deposition of solar cells was studied experimentally. Dust particles were first dryly deposited on the glass 
sample with and without a super-hydrophilic coating and then the water spraying was conducted to remove the deposited dust particles. The micro-patterns of dust deposition, dust deposition mass, and transmittance of glass samples after water spraying were studied in the present study. The conclusions are as follows:

1. Many dust particles adhere and aggregate on the bare glass sample, while the particles deposited on the super-hydrophilic glass surface are densely distributed on the surface. In addition, the diameter of dust particles deposited on the bare glass samples are obviously larger than the coated glass cases.

2. When the water spraying was conducted, the dust deposition mass for bare and coated glass samples are both reduced obviously with the increased time of water spraying. The dust deposition mass on the coated glass sample is significantly lower compared with the bare glass sample. The self-cleaning efficiency of super-hydrophilic coating can reach more than $92 \%$, compared with the bare glass cases.

3. The dust deposition mass on the coated glass is $0.5,0.1,0.2$, and $0.1 \mathrm{mg}$ after the water spraying for Case $A^{*}, B^{*}, C^{*}$, and $D^{*}$, respectively. The dust deposition mass is obviously decreased with the increase in deposition and spraying tilt angles.

4. The spectral transmittance for all the coated cases is significantly higher than that for all the bare cases. The maximum transmittance improvement can reach $26.5 \%$ when the deposition tilt angle is $30^{\circ}$ and the spraying tilt angle is $60^{\circ}$.

Author Contributions: Conceptualization, H.L.; methodology, H.L.; experiment, W.Z.; writingoriginal draft preparation, W.Z.; writing-review and editing, H.L. Both authors have read and agreed to the published version of the manuscript.

Funding: The authors appreciate the financial support provided by the Xinjiang Science Fund for Distinguished Young Scholars (no. 2021D01E08), High-level Talents Project of Xinjiang University (No. 100521001), and Guangdong Basic and Applied Basic Research Fund (No. 2019A1515110555).

Institutional Review Board Statement: Not applicable.

Informed Consent Statement: Not applicable.

Data Availability Statement: Not applicable.

Conflicts of Interest: The authors declare no conflict of interest.

\section{References}

1. Shah, A.H.; Hassan, A.; Laghari, M.S.; Alraeesi, A. The Influence of Cleaning Frequency of Photovoltaic Modules on Power Losses in the Desert Climate. Sustainability 2020, 12, 9750. [CrossRef]

2. Zeedan, A.; Barakeh, A.; Al-Fakhroo, K.; Touati, F.; Gonzales, A.S. Quantification of PV Power and Economic Losses Due to Soiling in Qatar. Sustainability 2021, 13, 3364. [CrossRef]

3. Alquthami, T.; Menoufi, K. Soiling of photovoltaic modules: Comparing between two distinct locations within the framework of developing the photovoltaic soiling index (PVSI). Sustainability 2019, 11, 4697. [CrossRef]

4. Al-Housani, M.; Bicer, Y.; Koç, M. Assessment of various dry photovoltaic cleaning techniques and frequencies on the power output of cdte-type modules in dusty environments. Sustainability 2019, 11, 2850. [CrossRef]

5. El-Shobokshy, M.S.; Hussein, F.M. Effect of the dust with different physical properties on the performance of photovoltaic cells. Sol. Energy 1993, 51, 505-511. [CrossRef]

6. Kaldellis, J.K.; Kapsali, M. Simulating the dust effect on the energy performance of photovoltaic generators based on experimental measurements. Energy 2011, 36, 5154-5161. [CrossRef]

7. Goossens, D.; Van Kerschaever, E. Aeolian dust deposition on photovoltaic solar cells: The effects of wind velocity and airborne dust concentration on cell performance. Sol. Energy 1999, 66, 277-289. [CrossRef]

8. Lu, H.; Zhao, W. Effects of particle sizes and tilt angles on dust deposition characteristics of a ground-mounted solar photovoltaic system. Appl. Energy 2018, 220, 514-526. [CrossRef]

9. Lu, H.; Lu, L.; Wang, Y. Numerical investigation of dust pollution on a solar photovoltaic (PV) system mounted on an isolated building. Appl. Energy 2016, 180, 27-36. [CrossRef]

10. Lu, H.; Zhao, W. CFD prediction of dust pollution and impact on an isolated ground-mounted solar photovoltaic system. Renew. Energy 2019, 131, 829-840. [CrossRef]

11. Sueto, T.; Ota, Y.; Nishioka, K. Suppression of dust adhesion on a concentrator photovoltaic module using an anti-soiling photocatalytic coating. Sol. Energy 2013, 97, 414-417. [CrossRef] 
12. Adachi, T.; Latthe, S.S.; Gosavi, S.W.; Roy, N.; Suzuki, N.; Ikari, H.; Inoue, T. Photocatalytic, superhydrophilic, self-cleaning TiO2 coating on cheap, light-weight, flexible polycarbonate substrates. Appl. Surf. Sci. 2018, 458, 917-923. [CrossRef]

13. Fujishima, A.; Rao, T.N.; Tryk, D.A. TiO 2 photocatalysts and diamond electrodes. Electrochim. Acta 2000, 45, 4683-4690. [CrossRef]

14. de Jesus, M.A.M.L.; Timò, G.; Agustín-Sáenz, C.; Braceras, I.; Cornelli, M.; de Mello Ferreira, A. Anti-soiling coatings for solar cell cover glass: Climate and surface properties influence. Sol. Energy Mater. Sol. Cells 2018, 185, 517-523. [CrossRef]

15. Piliougine, M.; Cañete, C.; Moreno, R.; Carretero, J.; Hirose, J.; Ogawa, S.; Sidrach-de-Cardona, M. Comparative analysis of energy produced by photovoltaic modules with anti-soiling coated surface in arid climates. Appl. Energy 2013, 112, 626-634. [CrossRef]

16. Quan, Y.Y.; Zhang, L.Z. Experimental investigation of the anti-dust effect of transparent hydrophobic coatings applied for solar cell covering glass. Sol. Energy Mater. Sol. Cells 2017, 160, 382-389. [CrossRef]

17. Pan, A.J.; Lu, H.; Zhang, L.Z. Experimental investigation of dust deposition reduction on solar cell covering glass by different self-cleaning coatings. Energy 2019, 181, 645-653. [CrossRef]

18. Lu, H.; Cai, R.R.; Zhang, L.Z.; Lu, L.; Zhang, L.F. Experimental investigation on deposition reduction of different types of dust on solar PV cells by self-cleaning coatings. Sol. Energy 2020, 206, 365-373. [CrossRef]

19. Prabhu, S.; Cindrella, L.; Joong Kwon, O.; Mohanraju, K. Superhydrophilic and self-cleaning rGO-TiO2 composite coatings for indoor and outdoor photovoltaic applications. Sol. Energy Mater. Sol. Cells 2017, 169, 304-312. [CrossRef]

20. Lei, F.; Chen, S.M.; Sun, H.Y.; Han, H.; Yang, J.L.; Huang, J.T.; Li, D.D.; Sun, D.Z. Fabrication of highly transparent and superhydrophilic coatings on glass by modified $\alpha$-zirconium phosphate nanoplatelets. Mater. Chem. Phys. 2021, $263,124377$. [CrossRef]

21. Centeno, P.; Alexandre, M.F.; Chapa, M.; Pinto, J.V.; Deuermeier, J.; Mateus, T.; Fortunato, E.; Martins, R.; Águas, H.; Mendes, M.J. Self-Cleaned Photonic-Enhanced Solar Cells with Nanostructured Parylene-C. Adv. Mater. Interfaces 2020, 7, 2000264. [CrossRef]

22. Khan, M.U.; Abbas, M.; Khan, M.M.; Kousar, A.; Jafri, M. Modeling and design of low-cost automatic self cleaning mechanism for standalone micro PV systems. Sustain. Energy Technol. Assess. 2021, 43, 100922.

23. Lebbi, M.; Touafek, K.; Benchatti, A.; Boutina, L.; Baissi, M.T. Energy performance improvement of a new hybrid PV/T Bi-fluid system using active cooling and self-cleaning: Experimental study. Appl. Therm. Eng. 2021, 182, 116033. [CrossRef]

24. Allouhi, A. Solar PV integration in commercial buildings for self-consumption based on life-cycle economic/environmental multi-objective optimization. J. Clean. Prod. 2020, 270, 122375. [CrossRef]

25. Roslizar, A.; Dottermusch, S.; Vüllers, F.; Kavalenka, M.N.; Guttmann, M.; Schneider, M.; Paetzold, U.W.; Hölscher, H.; Richards, B.S.; Klampaftis, E. Self-cleaning performance of superhydrophobic hot-embossed fluoropolymer films for photovoltaic modules. Sol. Energy Mater. Sol. Cells 2019, 189, 188-196. [CrossRef]

26. Liu, T.; Li, X.F.; Wang, D.H.; Huang, Q.L.; Liu, Z.; Li, N.N.; Xiao, C.F. Superhydrophobicity and regeneration of PVDF/SiO 2 composite films. Appl. Surf. Sci. 2017, 396, 1443-1449. [CrossRef]

27. Mouchaal, Y.; Enesca, A.; Mihoreanub, C.; Khelil, A.; Duta, A. Tuning the opto-electrical properties of $\mathrm{SnO}_{2}$ thin films by Ag+1 and In+3 co-doping. Mater. Sci. Eng. B 2015, 199, 22-29. [CrossRef]

28. Sangchay, W. The self-cleaning and photocatalytic properties of $\mathrm{TiO}_{2}$ doped with $\mathrm{SnO}_{2}$ thin films preparation by sol-gel method. Energy Procedia 2016, 89, 170-176. [CrossRef]

29. Yiu, P.; You, J.D.; Wang, S.T.; Chu, J.P. Tunable hydrophilicity in a surface nano-textured stainless steel thin film deposited by DC magnetron sputtering. Appl. Surf. Sci. 2021, 555, 149705. [CrossRef]

30. Jiang, H.; Lu, L.; Sun, K. Experimental investigation of the impact of airbourne dust deposition on the performance of solar photovoltaic (PV) modules. Atmos Environ. 2011, 45, 4299-4304. [CrossRef] 